\title{
Ruminants as part of the global food system: how evolutionary adaptation sand diversity of the digestive system brought them to the future
}

\begin{abstract}
The importance of wild and domestic ruminants is evident to either habitat equilibrium or food production. Ruminants went through a series of evolutionary steps influenced by the environment and severe climate shifts, and adapted to different nutritional diets until the modern changes of the actual food demand. Evolutionary studies suggest that strict extremes of cattle and moose-type evolved from more rudimentary intermediate-type ruminants. Also, ruminants have been shown with extraordinary adaptive mechanisms of digestibility efficiency, regardless the body size and ability to regulate water in drought conditions. Incorporation of relatively high proportions of easily degradable carbohydrates in the diet of ruminants is doing more than increasing the chance of ruminal/metabolic diseases. Nowadays, the food demand caused by the increase in human population has forced ruminant production systems to change the fiber based diet to larger proportions of grains and evolutionary responses to these new challenges will be dependent of future research. Morphology, physiology, nutrition and evolution knowledge will help to minimize injuries to ruminant health and to obtain the production efficiency required for the modern world.
\end{abstract}

Keywords: food production, ruminal, physiology, animal evolution, ruminant anatomy, adaptive mechanisms
Volume 3 Issue 5 - 2016

\author{
Saulo Gusmão da Silva de Tarso,' Daniela \\ Oliveira, ${ }^{2}$ José Augusto Bastos Afonso ${ }^{3}$ \\ 'Department of Animal Science, Food and Nutrition, Southern \\ Illinois University, USA \\ 2Departamento de Anatomia, Universidade Federal Rural de \\ Pernambuco, Brazil \\ ${ }^{3}$ Clínica de Bovinos de Garanhuns, Universidade Federal Rural \\ de Pernambuco, Brazil
}

Correspondence: Saulo Gusmão da Silva de Tarso, Department of Animal Science, Food and Nutrition, Southern Illinois University, USA, Email stdetarso@hotmail.com

Received: May 18, 2016 | Published: July 27, 2016
Abbreviations: HC, high-concentrate; VFA, volatile fatty acids; RFI, residual feed intake

\section{Introduction}

Ruminants as a part of the livestock structure, occupy an important role on the present and future of the global food system, ${ }^{1}$ and on the maintenance of environmental equilibrium in wild habitats. ${ }^{2}$ The challenge of feeding a growing population (more than 9billion people by 2050), together with changes in consumption patterns will increase the demand for livestock products. ${ }^{1,3-5}$ Therefore, some authors call these prospective "the livestock revolution" ${ }^{1-8}$ thereby strengthening the role of ruminants ${ }^{9}$ as a forceful part of the world food economy.

Livestock systems are substantial users of natural resources, which raises a red flag between food production and the resource use efficiency. Against this background, the social benefits of livestock systems, and how they contribute significantly to the livelihoods of at least 1.3 billion people in rural areas has been focus of substantial public debate ${ }^{6,9}$ Moreover, detailed reviews on ecology and evolution showed the large population of domestic ruminants ${ }^{10}$ (Figure 1), and their importance in recent projections since the total meat and milk consumption in different parts of the world will double by $2050.5,6,8$ Thus, considering that domestic ruminants are responsible to produce $50 \%$ of the meat and $41 \%$ of milk between the developing and developed countries (Table 1), ${ }^{12-15}$ the understanding of ruminant biology has a substantial relevance for future food production.

Concerns of how to feed a growing populations and the importance of ruminants in support of humans are not restrict to recent projections. ${ }^{16}$ Classic researches from the 70's and 80's explored the mammalian evolution ${ }^{17}$ and importance of ruminants to the man. ${ }^{16,18}$
Authors claim that some species are bioindicators of the first order in polluted human environments. More species are living barometers of man's in-ability to understand and handle ecological interactions and most, if not all ruminant species can benefit nutritionally from what man cannot digest. ${ }^{18}$ The feeding behavior of ruminants is peculiar to each specie and the environment in which they are included, with morphological and physiological traits of each type of food available in different types of vegetation. ${ }^{2}$

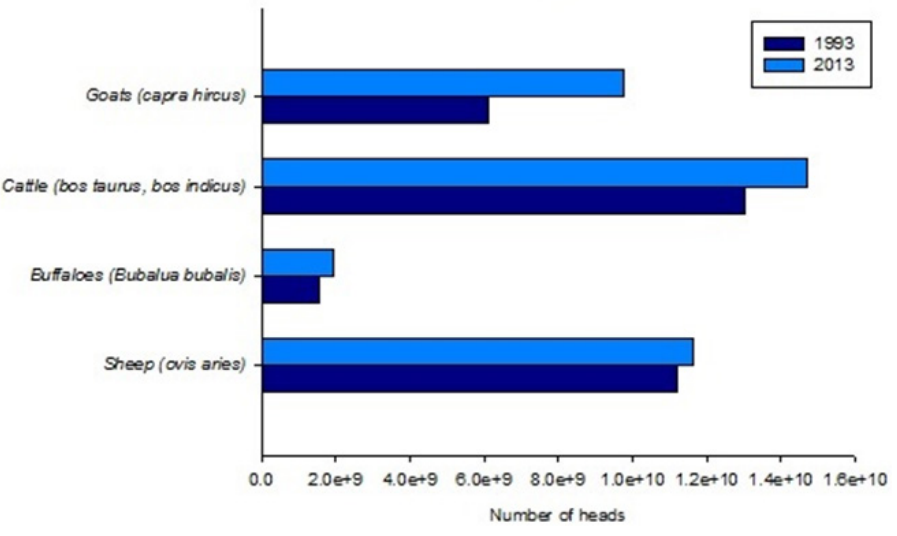

Figure I World population of domestic ruminant species-heads of animals (1993 and 2013)."

The production capability of domestic ruminants has changed for the past decades, either by the massive genetic improvements to attend the consumption demand, or by the natural evolution throughout the centuries. ${ }^{19}$ Taking this background together, this review aims to depict the environmental and evolutionary aspects of domestic and wild ruminants, regarding the digestive conversion capability; 
morphophysiological differences among species and the prospective for the future in terms of effects on productivity in future evolutionary adaptation in livestock ruminants.

\section{Historical components to evolution of ruminants}

The global climate environment shifts during late Pliocene, indicating some of the most important events of mammals' evolution. ${ }^{20-22}$ The declining temperatures, increased amplitude of climate cycles, and shifts in the orbital climate periodicity, indicating that pastures appeared in developed semi-arid areas. ${ }^{23}$ The cooling of earth occurred at various stages, separated by relative heating periods. These alternating cycles caused significant climatic changes and habitat modifications, ${ }^{22}$ and favored plants with spaced distribution and a high nutritional value. Some herbivore' species have evolved early and have adapted to the consumption of this type of vegetable. ${ }^{17,24}$

The evolution of herbivores followed the interaction between plants and animals. Many plants have used animals as vectors for seed dispersal, and several animals have adapted their requirements according to the environmental food availability. ${ }^{25}$ Conjectures that changes in the resource-use specialization rate of ungulates, more precisely the evolution and incorporation of the grazing, were pushed by the expansion of $\mathrm{C} 4$ grasslands in Africa during the early Pliocene. ${ }^{26,27}$ Palaeoecological evidences claim that the ancestral ruminant was a small and forest-dwelling species $^{28}$ with feeding characteristics of a browser/mixed feeder, and therefore with a leafeating style, rich in intracellular carbohydrates ${ }^{29-31}$ For ruminants, grazing meant a less selective eating pattern and more developed cellulolytic ruminal fermentation. ${ }^{32}$ The development of fermentation chambers facilitated the utilization of slow digestive food sources such as fibrous forage. This adaptation also coincided with the colder and drier climates, propelling less differentiated and developed forages, perhaps with high nutritional value for animals that had adequate cellulolytic capacity in the rumen. . $^{2,32}$

Lately, plants have developed some protection mechanisms against animals, lowering the availability of nutrients and leading animals to evolutionary response to various strategic feeding alternatives. ${ }^{33}$ These environmental changes effect geographical limitations that are needed to regulate primary speciation and extinction events, ${ }^{22}$ leading to the extinction of a large number of monogastric herbivores. ${ }^{20}$ Speculation that the interaction of climate change and feeding strategies around the world, favored ruminants in relation to horses and other large monogastric herbivores. This occurred because the smaller ruminants required smaller amounts of food, and had more efficient energy extraction. ${ }^{17}$

Ruminants that evolved later adapt to a less rich diet, following the development of pastures with grasses and other fibrous vegetables, being called in this classification as grazers (see classification below). Belonging to this group are the cattle, domestic and wild sheep and many antelope species of African savannas as well as American and European bison. ${ }^{20,23,34}$ Furthermore, because morphological evolution occurs more rapidly than speciation and taxonomic turnover, the variety of diets and ecological niches that occur within ungulate herbivores exceeds even their species richness. ${ }^{35}$

Despite the fact that usually is speculated that intermediate and grazer ruminants evolved originally from browser feeders, ${ }^{18,30}$ current indication advocate the strict extremes of grazers and browsers evolved from more rudimentary intermediate-type ruminants. ${ }^{35-37}$

Table I Mundial production of milk and meat from different domestic ruminant species."

\begin{tabular}{|c|c|c|c|c|}
\hline & Buffalo & Cattle & Goat & Sheep \\
\hline \multicolumn{5}{|c|}{ Meat (million tons) } \\
\hline Africa & $390,000.00$ & $5,694,270.70$ & I,30I,339.13 & $\mathrm{I}, 687,934.45$ \\
\hline Asia & $3,320,526.70$ & $14,373,105.40$ & $3,805,642.70$ & $4,254,075.25$ \\
\hline Central America & -- & $2,264,038.01$ & $40,540.20$ & $6 \mathrm{I}, \mathrm{I} 20.50$ \\
\hline Europe & $12,272.00$ & $10,140,072.00$ & II $2,260.40$ & $I, I 30,147.60$ \\
\hline North America & -- & $12,754,389.00$ & 1.88 & $90,280.00$ \\
\hline Oceania & 0.9 & $2,90 I, 428.90$ & $27,329.18$ & $\mathrm{I}, \mathrm{I} 10,589.00$ \\
\hline South America & -- & $15,617,998.75$ & $73,491.48$ & $242,076.34$ \\
\hline \multicolumn{5}{|c|}{ Milk (million tons) } \\
\hline Africa & $2,6 \mid 4,500.00$ & $34,120,566.10$ & $4,184,887.00$ & $2,250,650.00$ \\
\hline Asia & $77,290,169.00$ & $177,475,135.00$ & $10,653,508.50$ & $4,823,340.00$ \\
\hline Central America & -- & $\mid 4,687,010.00$ & $155,354.00$ & -- \\
\hline Europe & $203,791.00$ & $210,277,938.00$ & $2,526,426.00$ & $3,021,664.00$ \\
\hline North America & -- & $99,666,528.00$ & -- & -- \\
\hline Oceania & -- & $28,475,108.60$ & 50 & -- \\
\hline South America & -- & $69,115,338.00$ & $220,162.00$ & $42,095.00$ \\
\hline
\end{tabular}




\section{The progress of ruminant classification}

A pioneer classification was proposed by Hofmann ${ }^{18,34,38,39}$ regarding to the type of food ingested among herbivores, taking into account the anatomical and evolutionary aspects of the digestive system. This classification has been criticized because of the lack of data and statistical analysis. ${ }^{30,40,41}$ Hofmann classify ruminants in three different types (concentrate selectors, intermediate and grazers) using botanical and nutritive observations of the diet. ${ }^{42,43}$ The terminology "concentrated selector" used for Hofmann as a description of browsing ruminants is recently avoided, since concepts that integrally describes both botanical and nutritive aspects have been developed, explaining evolutionary adaptation properly rather than the botanical approach only. ${ }^{19}$

More recently, studies reported that, despite the wealth of the schemes and the initiative to classify herbivores according to the chemical composition of the diet, Hofmann's classification was criticized for basing his rating on photographic data that make it difficult to pursue for potential followers. ${ }^{44}$ Therefore, even though the botanic and dietary quality terminology used for Hofmann is valuable, other terms that describes morphological types should be considered. ${ }^{19}$

Hence, later classifications consider the ruminal physiology to differentiate ruminants in two extremes; "cattle-type' and "moosetype". ${ }^{19}$ In a comparative study, the differences in rumen contents stratification and papillation were found between extreme grazers (cattle-type) and extreme browsers (moose-type). Cattle-type have larger pre-stomach and thicker ruminal pillars (indicating the strength of the muscular apparatus in the reticulum) while the opposite occurs with the moose-type. ${ }^{45}$ These results explain a new hypothesis for the understanding of diversification of ruminants, concluding that due to lower capacity of the rumen-reticulum and the lack of an anatomical equipment to handle laminate ruminal contents, the moose-type are reluctant to pick up forage in the same proportion than grazers (cattle-type). ${ }^{19,45,46}$ Therefore these extremes in ruminal morphology emphasize the flexibility of ruminants in terms of digestive system. ${ }^{45}$

\section{Adaptive mechanisms in ruminants}

The rumen has an important adaptive role serving as a huge fermentation chamber and water tank. During periods of dehydration, the rumen is used as a storage chamber accommodating the water intake. The regulation of water intake and distribution is governed by the rumen, in conjunction with the salivary glands, and kidneys after acute dehydration and rehydration. ${ }^{47}$ One of the greatest advantages of the ruminants compared to other species of herbivores is the digestibility efficiency. After fermentation and ruminal absorption, some nutrients can still be digested and absorbed through the intestinal segments. ${ }^{24}$ In contrast, some herbivores which have anatomy and physiology of intestinal fermentation, are forced to practice coprophagy as a way of recovering nutrients not absorbed after fermentation, like some rodents.

Another way of recycling the nutrients is through the urea cycle, which ruminants reuse the urea from the blood stream, back to the rumen. ${ }^{48}$ The higher efficiency in terms of economizing its nitrogen is considered, since the urea will be an important source of nitrogen for the bacterial protein synthesis and a large part of the forages are not reach in this element. ${ }^{24,49}$

The climax of adaptation happens in goats and African antelopes living in arid climate. ${ }^{47,50}$ Under desert and tropical environments where feed resources are restricted in quantity and quality, ruminants present differences in the digestive tract. ${ }^{50-52}$ Upon these harsh circumstances ruminants show adjustment of energy requirements for maintenance and ability to reduce metabolism, regulation of water usage in drought conditions, ${ }^{47,50,53-55}$ competence to economize nitrogen, and thermoregulation by keratinized tissues. ${ }^{55,56}$ Small ruminants like goats are skilled grazers with a great ability to select food, they have an efficient digestive system that allows retain a great amount of food and also to efficiently utilize the most of the food during feed shortage conditions. ${ }^{47,52}$

\section{Fiber digestibility and body size}

Throughout the years, the rate of evolution of the fiber digestibility accelerated. This may have been caused by a combination of increased competition between species of ruminants and adaptation to highfiber diets, both related to environmental changes of the past million years. ${ }^{31}$

Extensive debate has been done regarding adaptations to a variety of environments and whether or not the body size of ruminants present differences in terms of ability to digest fiber. ${ }^{19,31,46,57-60}$ Controverting reports were published on ruminant species with small body size (smaller than $20 \mathrm{~kg}$ ), having. ${ }^{33}$ or not ${ }^{61}$ a better ability to digest fiber, and evaluating the time retaining fiber in the rumen. ${ }^{59,62,63}$ It seems that there is an agreement in regard to larger animals requiring larger amounts of food, and the more abundant plants are usually lower in nutritional value. Therefore, herbivores with higher body mass would have low quality diet. ${ }^{64}$ Perhaps, it comes out that any digestive advantage that is derived by the body size has not been clearly supported by empirical methods..$^{58,63,65,66}$ It is suggested that models to explain herbivore's size diversification must change their physiological views to ecological, considering the associations of food quality and availability, and body mass and food selectivity. ${ }^{46}$ Otherwise, these models would not totally explain herbivore's size diversification, leading to the understand that large herbivores would tend to feed less selectively and would only use low-quality forage, while small herbivores use any forage that they can physically handle. ${ }^{46,58}$ Furthermore, evolutionary adaptations to ecological feed opportunities can explain the rare existence of some small ruminants feeding low-quality forage, rather than only physiological or metabolic needs related to body mass. ${ }^{46,60}$

\section{The new scenario of diets for domestic ruminants}

Throughout the years, has been remarkable the incorporation of a relatively large percentage of easily degradable carbohydrates in the diet of ruminants in intensive production systems. ${ }^{67,68}$ This "nutritional boost" is supported by the high production of milk or rapid weight gain provided by these diets. ${ }^{69}$ Despite the fact that these feeding shifts might enhance the production efficiency, they are not ideally health for ruminal physiology. ${ }^{70-72}$

Modern production systems include several practices and many dietary changes during different physiological stages. ${ }^{73}$ The addition of rapidly fermentable nonstructural carbohydrates lowers the proportion of ruminal fiber, changes the pattern of gas production, and increase the chances of metabolic and ruminal diseases..$^{71,74}$ Recent studies found that a long-term feeding a high-concentrate (HC) diet induces accumulation of volatile fatty acids (VFA) in ruminal fluid and colonic digesta, and damages the colonic mucosa inducing cell apoptosis in lactating goats. ${ }^{68,75}$ Additionally, goats under the same 
HC diet conditions showed omasal epithelial cellular damage and changes in the expression of tight junctions proteins, which may increase the omasal epithelial permeability, thereby increasing the risk of translocation of microbial products into the circulation. ${ }^{67}$

In cattle, recent studies showed that under long term $\mathrm{HC}$ diets and subacute ruminal acidosis episodes, there is an epithelial adaptation in the rumen. Novel transcriptomic approaches elucidate the molecular mechanisms controlling rumen epithelial metabolic adaptation to $\mathrm{HC}$ diets, discovering that there is an involvement of transcriptional factors that may play an important role in the metabolic adaptation of the rumen epithelium to HC diets. ${ }^{76}$ Signs of adaptation include proliferation, differentiation, and up regulation of genes and transcriptional factors involved in the thickness of the ruminal stratified squamous rumen epithelium. ${ }^{76,77}$

Despite the fact that dietary changes can increase the chance of ruminal/metabolic diseases, the nutritional shifts made during the past decades may cause more drastic modifications to the future evolutionary adaptations of the digestive system. Studies observed that the resting breath frequency in the modern cattle is more than twice the frequency of the horse of approximately the same size. It's believed that with evolution, the cattle-type ruminants developed a larger fore stomach capacity than in the other ruminant families. This may have led to a space competition with other organs, translating in a compensatory higher respiratory rates and differences in feces consistency. ${ }^{44,78}$

Additionally, since the advent of whole-genome association studies, another recent research trend has increased the interest in genetically breeding to improve cattle feed efficiency. Based on genetic/physiological evidences of individual animal variation in feed intake, studies are trying to enable genetic selection of cattle for residual feed intake (RFI) to improve production system efficiency. ${ }^{79,80}$ Regardless of multiple markers have been described in several studies, no major gene affecting RFI has been found..$^{80-83}$

\section{Conclusion}

Modern food demand caused by the increase in human population has forced ruminant production systems to change the fiber based diet to larger proportions of grains. The major changes in ruminant diets have been strongly made during the last decades in commercial production systems with the aim of maximizing production efficiency. Incorporation of relatively high proportions of easily degradable carbohydrates in the diet of ruminants is doing more than increasing the chance of ruminal/metabolic diseases, but causing a side effect in response to the downturn in fiber proportion of diets. New functional abilities take a long time to turn into morphological changes and to be considered evolved. Thus, morphology, physiology, nutrition and evolution knowledge must be taken into account in order to minimize injuries to ruminant health and to obtain the production efficiency required for the modern world.

\section{Acknowledgements}

The authors gratefully acknowledge Gustavo Desire Antunes Gastal for the critical revising of the content of this review.

\section{Conflict of interest}

The authors declare that there is no conflict of interest that could be perceived as prejudicing the impartiality of the review reported.

\section{References}

1. Herrero M, Thornton PK. Livestock and global change: emerging issues for sustainable food systems. Proc Nat Acad Sci USA. 2013;110(52):20878-20881.

2. Hungate R, Phillips G, McGregor A, et al. Microbial fermentation in certain mammals. Science. 1959;130(3383):1191-1194.

3. Godfray HCJ, Beddington JR, Crute IR, et al. Food security: the challenge of feeding 9 billion people. Science. 2010;327(5967):812-818.

4. Godfray HCJ, Crute IR, Haddad L, et al. The future of the global food system. Philos Trans R Soc Lond. B Biol Sci. 2010;365(1554):2769-2777.

5. Gerosa S, Skoet J. Milk availability Trends in production and demand and medium-term outlook. FAO Corporate Document Repository. 2012;1-40 p.

6. Delgado C, Rosegrant M, Steinfeld H, et al. Livestock to 2020: the next food revolution. Outlook Agric. 2001;30(1):27-29.

7. Steinfeld $H$. The livestock revolution-a global veterinary mission. Vet Parasito. 2004;125(1-2):19-41.

8. Alexandratos N, Bruinsma J. World agriculture towards 2030/2050 the 2012 revision. The 2012 Revision, Agricultural Development Economics Division, Food and Agriculture Organization of the United States Nations. Rome; 2012. p. 1-154.

9. Oltjen JW, Beckett JL. Role of Ruminant Livestock in Sustainable Agricultural Systems. J Anim Sci. 1996;74(6):1406-1409.

10. Herrero M, Thornton PK, Gerber P, et al. Livestock, livelihoods and the environment: understanding the trade-offs. Curr Opin Environ Sustain. 2009;1(2):111-120.

11. FAOSTAT. Food and Agriculture Organization of the United Nations Statistics Division. Livest Prim Prod Commodity. 2013.

12. Hackmann TJ, Spain JN. Invited review: ruminant ecology and evolution: perspectives useful to ruminant livestock research and production. J dairy Sci. 2010;93(4):1320-1334.

13. Steinfeld H, Gerber P, Wassenaar T, et al. Livestock's long shadow: environmental issues and options. Italy: Food and Agriculture Organization of the United Nations. 2006.

14. McMichael AJ, Powles JW, Butler CD, et al. Food, livestock production, energy, climate change, and health. Lancet. 2007;370(9594):1253-1263.

15. Steinfeld H, Gerber P. Livestock production and the global environment: consume less or produce better? Proc Natl Acad Sci U S A. 2010;107(43):18237-18238.

16. Fitzhugh HA, Hodgson HJ, Scoville OJ, et al. The role of ruminants in support of man. Morrilton, Arkanas: Winrock International; 1978.

17. Marshall LG, Webb DS, Sepkoski JJ, et al. Mammalian Evolution and the Great American Interchange. Science. 1982;215(4538):1532-1357.

18. Hofmann R. Evolutionary steps of ecophysiological adaptation and diversification of ruminants: a comparative view of their digestive system. Oecologia. 1989;78(4):443-457.

19. Clauss M, Hume I, Hummel J. Evolutionary adaptations of ruminants and their potential relevance for modern production systems. Animal. 2010;4(7):979-992.

20. Bobe R, Behrensmeyer AK, Chapman RE. Faunal change, environmental variability and late Pliocene hominin evolution. J Hum Evol. 2002;42(4):475-497.

21. Vrba ES. Ecological and adaptive changes associated with early hominid evolution. Ancestors Hard Evid. 1st ed. In: E Delson, Alan Liss, editors. New York, USA; 1985;63-71. 
22. Vrba ES. Mammals as a key to evolutionary theory. J Mammal. 1992;73(1):1-28.

23. Bobe R, Behrensmeyer AK. The expansion of grassland ecosystems in Africa in relation to mammalian evolution and the origin of the genus Homo. Palaeogeogr Palaeoclimatol Palaeoecol. 2004;207(2004):399-420.

24. Van Soest PJ. Nutritional ecology of the ruminant. New York: Cornell University Press; 1994.

25. Olff H, Brown V, Drent R. Herbivores: Between Plants and Predators. 1999. 639p.

26. Rivals F, Semprebon GM. A comparison of the dietary habits of a large sample of the Pleistocene Pronghorn Stockoceros onusrosagris from the Papago Springs Cave in Arizona to the modern Antilocapra americana. $J$ Vertebr Paleontol. 2006;26(2):495-500.

27. Codron D, Codron J, Lee-Thorp J A, et al. Diets of savanna ungulates from stable carbon isotope composition of faeces. J Zool. 2007;273(1):21-29.

28. Janis CM. Evolution of horns in ungulates: ecology and paleoecology. Biol Rev Camb Phil Soc. 1982;57(2):261-318.

29. Janis CM. Miocene ungulates and terrestrial primary productivity: Where have all the browsers gone? Proc Nat Acad Sci. 2000;97(14):7899-7904.

30. Pérez-Barbería FJ, Gordon IJ, Nores C. Evolutionary transitions among feeding styles and habitats in ungulates. Evol Ecol Res. 2001;33:221-230.

31. Pérez-Barberia FJ, Elston DA, Gordon IJ, et al. The evolution of phylogenetic differences in the efficiency of digestion in ruminants. Proc Biol Sci. 2004;271(1543):1081-1090.

32. Janis C. Evolution of horns and related structures in hoofed animals. Discovery. 1986;19:9-17.

33. Van Soest PJ. Allometry and ecology of feeding behavior and digestive capacity in herbivores: A review. Zoo Biol. 1996;15(5):455-479.

34. Hofmann R. Morphophysiological evolutionary adaptations of the ruminant digestive system. Ithaca: Asp Dig Physiol ruminants Cornell University Press; 1988:1-20.

35. Codron D, Brink JS, Rossouw L, et al. Functional differentiation of African grazing ruminants: An example of specialized adaptations to very small changes in diet. Biol J Linn Soc. 2008;94(4):755-764.

36. Mann GE, Green MP, Sinclair KD, et al. Effects of circulating progesterone and insulin on early embryo development in beef heifers. Anim Reprod Sci. 2003;79(1-2):71-79.

37. DeMiguel D, Fortelius M, Azanza B, et al. Ancestral feeding state of ruminants reconsidered: earliest grazing adaptation claims a mixed condition for Cervidae. BMC Evol Biol. 2008;8:13.

38. Hofmann R. The ruminant stomach. Stomach structure and feeding habits of East African game ruminants. Kenya: East African Literature Bureau; 1973.

39. Hofmann R. Morphophysiological evolutionary adaptations of the ruminant digestive system. Ithaca: Asp Dig Physiol ruminants Cornell University Press; 1986. 311p.

40. Gordon IJ, Illius AW. Functional Significance of the Browser-Grazer Dichotomy in African Ruminants. Oecologia. 1994;98(8):167-175.

41. Robbins CT, Spalinger DE, van Hoven W. Adaptation of ruminants to browse and grass diets: are anatomical-based browser-grazer interpretations valid? Oecologia. 1995;103:208-213.

42. Robbins C. Animal feeding and nutrition. San Diego: Academic Press; 1993.
43. Clauss M, Kaiser T, Hummel J. The morphophysiological adaptations of browsing and grazing mammals. The Ecology of Browsing and Grazing. Heidelberg, Germany: Springer; 2008. p. 47-88.

44. Clauss M, Lechner-Doll M, Streich WJ. Ruminant diversification as an adaptation to the physicomechanical characteristics of forage. A reevaluation of an old debate and a new hypothesis. Oikos. 2003;102(2):253-262.

45. Clauss M, Hofmann RR, Fickel J, et al. The intraruminal papillation gradient in wild ruminants of different feeding types: Implications for rumen physiology. J Morphol. 2009;270(8):929-942.

46. Clauss M, Steuer P, Müller DWH, et al. Herbivory and body size: Allometries of diet quality and gastrointestinal physiology, and implications for herbivore ecology and dinosaur gigantism. PLoS One. 2013;8(10):e68714.

47. Silanikove N. The physiological basis of adaptation in goats to harsh environments. Small Rumin Res. 2000;35(3):181-193.

48. Cunha T, Shirley R. Nitrogen and Energy Nutrition of Ruminants. Hardbound, Gainesville; 1986.

49. Silanikove N, Tagari H, Shkolnik A. Gross energy digestion and urea recycling in the desert black Bedouin goat. Comp Biochem Physiol. 1980;67(1):215-218.

50. Woodall PF, Skinner JD. Dimensions of the Intestine, Diet and Fecal Water-Loss in Some African Antelope. J Zool. 1993;229(3):457-471.

51. McDowell LR. Nutrition of grazing ruminants in warm climates. Orlando, Florida: Academic Press; 1985.

52. Devendra C, Imaizumi E. Ruminant Physiology and Nutrition. Japan Society of Zootechnical Science. Sendai, Japan; 1990.

53. Dunson WA. Some aspects of salt and water balance of feral goats from arid islands. Am J Physiol. 1974;226:662-669.

54. Clauss M, Lechner-Doll M, Streich WJ. Differences in the range of faecal dry matter content between feeding types of captive wild ruminants. Acta Theriol. 2004;49(2):259-267.

55. Cain JW, Krausman PR, Rosenstock SS, et al. Mechanisms of Thermoregulation and water balance in Desert Ungulates. Wildl Soc Bull. 2006;34(3):570-581

56. Picard K, Thomas DW, Festa-Bianchet M, et al. Differences in the thermal conductance of tropical and temperate bovid horns. Ecoscience. 1999;6:148-58.

57. Clauss M, Schwarm A, Ortmann S, et al. A case of non-scaling in mammalian physiology? Body size, digestive capacity, food intake, and ingesta passage in mammalian herbivores. Comp Biochem Physiol A Mol Integr Physiol. 2007;148(2):249-265.

58. Müller DWH, Codron D, Meloro C, et al. Assessing the Jarman - Bell Principle: Scaling of intake, digestibility, retention time and gut fill with body mass in mammalian herbivores. Comp Biochem Physiol. 2013;164(1):129-140.

59. Steuer P, Südekum K, Müller DWH, et al. Is there an influence of body mass on digesta mean retention time in herbivores ? A comparative study on ungulates. Comp Biochem Physiol. 2011;160(3):355-364.

60. Steuer P, Südekum K-H, Tütken T, et al. Does body mass convey a digestive advantage for large herbivores? Funct Ecol. 2014;1-8 p.

61. Conklin-Brittain N Lou, Dierenfeld ES. Small ruminants: Digestive capacity differences among four species weighing less than $20 \mathrm{~kg}$. Zoo Biol. 1996;15(5):481-490.

62. Clauss M, Lechner-Doll M. Differences in selective reticulo-ruminal particle retention as a key factor in ruminant diversification. Oecologia. 2001;129:321-327. 
63. Steuer P, Südekum K, Müller DWH, et al. Fibre digestibility in large herbivores as related to digestion type and body mass -An in vitro approach. Comp Biochem Physiol. 2013;164:319-326.

64. Demment MW, Van Soest PJ. A nutritional explanation for bodysize patterns of ruminant and nonruminant herbivores. Am Nat. 1985;125(5):641-672.

65. Clauss M, Hummel J. The digestive performance of mammalian herbivores: Why big may not be that much better. Mamm Rev. 2005;35(2):174-187.

66. Wilkinson DM, Ruxton GD. High $\mathrm{C} / \mathrm{N}$ ratio (not low-energy content) of vegetation may have driven gigantism in sauropod dinosaurs and perhaps omnivory and/or endothermy in their juveniles. Funct Ecol. 2013;27(1):131-135.

67. Liu JH, Xu TT, Zhu WY, et al. A high-grain diet alters the omasal epithelial structure and expression of tight junction proteins in a goat model. Vet J. 2014;201(1):95-100.

68. Tao S, Duanmu Y, Dong H, et al. A high-concentrate diet induced colonic epithelial barrier disruption is associated with the activating of cell apoptosis in lactating goats. BMC Vet Res. 2014;10:235.

69. Plaizier JC, Krause DO, Gozho GN, et al. Subacute ruminal acidosis in dairy cows: The physiological causes, incidence and consequences. Vet J. 2008;176(1):21-31

70. Allen MS. Relationship between fermentation acid production in the rumen and the requirement for physically effective fiber. $J$ dairy $S c i$. 1997;80(7):1447-1462.

71. Enemark JMD, Jørgensen RJ, Enemark PS. Rumen acidosis with special emphasis on diagnostic aspects of subclinical rumen acidosis: a review. Vet IR Zootech. 2002;20(42):16-29.

72. Dijkstra J, Ellis JL, Kebreab E, et al. Ruminal $\mathrm{pH}$ regulation and nutritional consequences of low pH. Anim Feed Sci Technol. 2012;172(1-2):22-33.

73. Banninka A, Gerrits WJJ, France J, et al. Variation in rumen fermentation and the rumen wall during the transition period in dairy cows. Anim Feed Sci Technol. 2012;172(1-2):80-84.
74. Kleen JL, Hooijer GA, Rehage J, et al. Subacute ruminal acidosis (SARA) A review. J Vet Med A Physiol Pathol Clin Med. 2003;50(8):406-414.

75. Tao S, Tian J, Cong R, et al. Activation of cellular apoptosis in the caecal epithelium is associated with increased oxidative reactions in lactating goats after feeding a high-concentrate diet. Exp Physiol. 2015;100(3):278-287.

76. Steele MA, Vandervoort G, AlZahal O, et al. Rumen epithelial adaptation to high-grain diets involves the coordinated regulation of genes involved in cholesterol homeostasis. Physiol Genomics. 2011;43(6):308-316.

77. Steele MA, Croom J, Kahler M, et al. Bovine rumen epithelium undergoes rapid structural adaptations during grain-induced subacute ruminal acidosis. Am J physiol Regul Integr Comp Physiol. 2011;300(6):R1515$\mathrm{R} 1523$.

78. Mortola JP, Lanthier C. Breathing frequency in ruminants: A comparative analysis with non-ruminant mammals. Respir Physiol Neurobiol. 2005; $145(2-3): 265-277$.

79. Herd RM, Arthur PF. Physiological basis for residual feed intake. J Anim Sci. 2009;87(14 Suppl):64-71.

80. Moore SS, Mujibi FD, Sherman EL. Molecular basis for residual feed intake in beef cattle. J Anim Sci. 2009;87(14 Suppl):E41-E47.

81. Herd RM, Archer JA, Arthur PF. Reducing the cost of beef production through genetic improvement in residual feed intake: Opportunity and challenges to application. J Anim Sci. 2003;81(E Suppl 1):E9-E17.

82. Codron D, Brink JS, Rossouw L, et al. The evolution of ecological specialization in southern African ungulates: Competition- or physical environmental turnover? Oikos. 2008;117(3):344-353.

83. Iason G, Van Wieren S. Digestive and ingestive adaptations of mammalian herbivores to low-quality forage. Herbiv between plants predators. 1999. p. 337-369. 